\title{
MODEL NEGOSIASI POLITIK ANGGARAN DALAM PROSES PENETAPAN APBD PROVINSI SUMATERA UTARA
}

\author{
Martuama Saragi ${ }^{1}$, Tjahya Supriatna ${ }^{2}$, Sampara Lukman $^{3}$, Dety Mulyanti ${ }^{4}$ \\ ${ }^{1,2,3,4}$ Institut Pemerintahan Dalam Negeri (IPDN) \\ Email: martuama.saragih@ipdn@ac.id
}

\begin{abstract}
Abstrak
Tujuan penelitian ini adalah menemukan model baru negosiasi politik anggaran dalam proses penetapan APBD Provinsi Sumatera Utara. Penelitian ini merupakan penelitian kualitatif. Informan penelitian ini terdiri dari 13 orang yang ditentukan dengan snow ball sampling technique. Pengumpulan data dilakukan melalui studi kepustakaan, wawancara dan observasi. Analisis data penelitian menggunakan triangulasi. Hasil penelitian ini menemukan model baru dalam negoisasi politik anggaran yang disebut model negoisasi politik anggaran bernuansa positif. Model negoisasi politik anggaran bernuansa positif yaitu pola komunikasi pemerintahan yang berlangsung dalam perumusan, pembahasan dan penetapan kebijakan anggaran yang sepenuhnya untuk kepentingan publik dan anti korupsi, kolusi dan nepotisme yang terungkap dari motif negoisasi, dalil negoisasi dan konsekuensi negoisasi yang bernuansa positif. Hal ini mencakup tiga dimensi negoisasi politik anggaran, yaitu dimensi motif negoisasi anggaran bernuansa positif, dimensi dalil negoisasi anggaran bernuansa positif, dan dimensi konsekuensi negoisasi anggaran bernuansa positif.
\end{abstract}

Kata Kunci: Model Baru, Interaksi Politik, Politik Anggaran, Pemerintahan Daerah.

\begin{abstract}
The purpose of this study is to find a new model of budget political negotiation in the process of establishing the North Sumatra Province APBD. This research is a qualitative research. The informants of this study consisted of 13 people who were determined by the snow ball sampling technique. Data collection is carried out through literature study, interviews and observations. Analysis of research data using triangulation. The results of this study found a new model in budget political negotiations called the positive nuanced budget politics negotiation model. A positive nuanced budget politics negotiation model is a pattern of government communication that takes place in the formulation, discussion and determination of budget policies that are fully in the public interest and anti-corruption, collusion and nepotism that are revealed from the negotiation motives, the propositions of negotiations and the consequences of positive negotiations. This includes three dimensions of budget politics negotiation, namely the dimensions of the motives for positive nuanced budget negotiations, the dimensions of the proposition of positive nuanced budget negotiations, and the consequence dimensions of positive nuanced budget negotiations.
\end{abstract}

Keywords: New Model, Political Interaction, Budget Politics, Local Government. 


\section{ARTIKEL}

\section{A. PENDAHULUAN}

Salah satu tahapan manajemen keuangan daerah Provinsi Sumatera Utara yang terdiri atas 25 Kabupaten dan 8 Kota yang paling menentukan kinerja keuangan daerah adalah tahapan penyusunan dan penetapan Anggaran Pendapatan dan Belanja Daerah (APBD). Dari penetapan APBD dapat diketahui kebijakan dan strategi Pemerintahan Provinsi Sumatera Utara dalam mengelola sumber-sumber pendapatan daerah serta mendistribusikan belanja daerah hingga terlaksananya berbagai kebijakan dan kegiatan pemerintahan, pembangunan, pelayanan publik dan pemberdayaan masyyarakat.

Agak sulit merumuskan kebijakan dan strategi keuangan daerah hingga mencapai kesepakatan tertentu. Kesulitan yang dimaksud timbul karena kesepakatan atas kebijakan dan strategi keuangan daerah harus melibatkan dua lembaga pemerintahan daerah, yaitu Pemerintah Daerah dan DPRD. Masing-masing lembaga tentu memiliki otoritas tersendiri namun dalam penyelenggaraan sistem pemerintahan daerah harus bersinergi. Proses sinergitas otoritas ini tentu tidak lepas dari pengaruh dinamika interaksi politik di antara pejabat eksekutif dengan anggota legislatif. Dengan kedudukan dan peran politik yang berbeda namun harus bersinergi tentu terjadi suatu proses interaksi politik di antara pejabat eksekutif dengan anggota legislatif. Interaksi politik dalam proses penetapan APBD merupakan suatu rangakain aktivitas komunikasi pemerintahan yang mempunyai tujuan tertentu. Tujuan yang dimaksud tentu tidak lepas dari pengaruh kepentingan masing-masing pihak.

Dari kegiatan penelitian pendahuluan terindentifiksi bahwa interaksi politik yang berlangsung dalam proses penetapan APBD Provinsi Sumatera Utara masih belum optimal. Belum optimalnya interaksi politik bisa bernuansa positif dan bisa juga bernuansa negatif. Bernuansa positif apabila dalam proses interaksi politik tersebut sepenuhnya tertuju pada kepentingan masyarakat. Dalam nuansa positif tentu sulit menemukan praktek-praktek korupsi, kolusi dan nepotisme (KKN). Bernuansa negatif apabila dalam proses interaksi politik tersebut tidak sepenuhnya tertuju pada kepentingan masyarakat, dan bahkan mengindikasikan adanya praktek-praktek KKN. Praktek-praktek KKN jelas tidak hanya merugikan negara namun secara langsung atau tidak langsung dapat menyusahkan masyarakat, terutama masyarakat miskin.

Sementara itu, dari fenomena perilaku korupsi yang melibatkan Gubernur dan sejumlah Anggota DPRD Provinsi Sumatera Utara pada beberapa tahun silam jelas terindikasikan bahwa proses interaksi politik dalam proses penetapan APBD memang dapat menjadi peluang bagi 
terjadinya praktek-praktek KKN di antara pejabat eksekutif dengan anggota legislatif. Artinya, interaksi politik yang berlangsung dalam penetapan APBD yang belum optimal untuk sepenuhnya merepresentasikan kepentingan dan harapan masyarakat Sumatera Utara bisa terjadi karena adanya praktek-praktek KKN.

Belum optimalnya interaksi politik dalam proses penetapan APBD Provinsi Sumatera Utara tampak menjadi suatu fenomena komunikasi pemerintahan yang menarik untuk diteliti. Tujuan penelitian ini adalah menemukan model baru negosiasi politik anggaran dalam proses penetapan APBD Provinsi Sumatera Utara.

\section{B. METODE PENELITIAN}

Penelitian menggunakan penelitian kualitatif dengan post positivist paradigm (Creswel, 1994; Arikunto, 2007). Informan penelitian sebanyak 13 orang ditentukan dengan snowball sampling technique. Pengumpulan data sekunder dari berbagai buku dan dokumen menggunakan studi kepustakaan; pengumpulan data primer dari para informan penelitian menggunakan teknik wawancara dan observasi. Analisis data menggunakan teknik triangulasi.

\section{HASIL DAN PEMBAHASAN}

Teori Interaksi Politik: Zeehandelaar (2012:8) mengatakan bahwa aktor menggunakan proses rasional untuk mencapai tujuan khusus organisasi melalui manajemen struktur, menggunakan tawar menawar dan negosiasi untuk memastikan bahwa kepentingan mereka dan kepentingan orang-orang yang mereka wakili aman. Berdasarkan teori interaksi politik Zeehandelaar disusun definisi konsepetual bahwa Interaksi Politik dalam proses penetapan Anggaran Pendapatan dan Belanja Provinsi Sumatrera Utara adalah proses komunikasi pemerintahan yang berlangsung dalam pelaksanaan prosedur dan mekanisme penetapan Anggaran Pendapatan dan Belanja Provinsi Sumatera Utara yang terungkap dari penggunaan proses rasional, manajemen struktur, tawar menawar dan negoisasi. Dari definisi konspetual diturunkan empat imensi analisis : (1) Dimensi penggunaan proses rasional, (2) Dimensi manajemen struktur, (3) Dimensi penggunaan tawar menawar, dan (4) Dimensi negoisasi.

Dari deskirpsi analisis hasil wawancara dengan Informan Penelitian terungkap hal-hal yang dapat dinyatakan sebagai fakta empirik yang dominan dan menjadi temuan penelitian 
ARTIKEL

(research finding). Temuan empirik yang dimaksud tercakup dalam Dimensi Negoisasi yang merujuk pada empirik berikut:

Pertama, interaksi politik yang dilakukan dengan negoisasi dalam proses pentepan ABPD Provinsi Sumatera Utara pada dasarnya berfungsi untuk menyampaikan pesan tertentu dari satu pihak kepada pihak lainnya. Negoisasi merupakan salah satu aksi komunikasi politik yang dilakukan untuk tujuan tertentu, menurut kepentingan tertentu yang menjadi motivasi pelaku negoisasi. Walaupun secara formal negoisasi itu bertujuan untuk menggalang kesepakatan untuk kepentingan bersama; namun kenyataannya bisa saja negoisasi itu dilakukan untuk kepentingan tertentu yang tidak relevan dengan fungsi normatif anggaran. Dalam konteks ini, seorang Informan mengungkapkan:

Pada prinsipnya mekanisme loby yang mengarah kepada negoisasi dapat berdampak positif maupun negatif. Negatif apabila hasil negoisasi tersebut tidak sesuai dengan harapan pemerintah maupun masyarakat; dan sebaliknya positif apabulan negoisasi tersebut dapat menyelesaikan masalah yang sesuai dengan harapan masyarakat.

Seorang informan lainnya mengatakan:

Tujuan negoisasi, menurut temanku, supaya mendapat persetujuan anggaranlah. Jadi sebenarnya mereka itu yang jual beli kekuasaan....... Alaa mak, jangan begitulah. Kalau memang begitu, ya apa mau dikata, motifnya pastilah keuntungan pribadi dan keuntungan untuk orang lain. Keuntungan ini dibungkus dengan cerita seolah-olah untuk kepentingan rakyatlah. Alaaa mak....ini benar-benar motif negoisasi yang negatif tak baiklah untuk kita.

Kedua, idealnya dalil itu didasarkan pada aturan formal, kebijakan yang faktual, kepentingan bersama yang merujuk pada kondisi obyektif kehidupan rakyat. Bagaimana dinamika interaksi politik yang terjadi di antara pejabat eksekutif dan anggota legislatif dalam menjelaskan dan mempertahankan dalilnya, tergantung pada motivasi dan kepentingan yang mempengaruhi dalilnya. Dalam konteks ini, seorang Informan mengungkapkan :

Apakah berdalil itu salah? Tidak. Justru dalil negoisasi itu penting sekali agar supaya orang yang diajak bicara merasa yakin, benar terhadap apa yang didalilkannya. Seandainya dalil itu berdasarkan fakta, benar adanya, anggaran itu memang sangat dibutuhkan, apa lagi, pokoknya semua disampaikan secara jujur dan terbuka menurutku tidak jadi masalah. Bagus itu. Tapi bagaimana seandainya dalil yang mereka sampaikan itu sebenarnya kebohongan, atau katakalah mengada-ada? Dalil itu sebenarnya bisa dijadikan cara untuk mendapat sesuatu, keuntungan atau imbal jasa dari besaran anggaran yang dinegoisasikan. Dalil negoisasi anggaran yang direkayasa untuk mendapat sesuatu, keuntungan atau imbal jasa dari besaran anggaran yang dinegoisasikan itu sebenarnya merupakan suatu peristiwa KKN. Dalil 
seperti inilah yang kusebut dalil negoisasi anggaran yang negatif, karena dilakukan dengan kebohongan, dengan maksud tertentu yang bisa merugikan negara.

Ketiga, konsekuensi logis negoisasi yang dilakukan oleh pejabat eksekutif atau anggota legislatif adalah bahwa salah satu pihak harus mau memahami dan sekaligus mengikuti kemauan atau kepentingan pihak lainnya. Untuk itu, tentu saja ada kompensasi yang diberikan satu pihak kepada pihak lainnya, yang ngotot menujukkan posisi politiknya. Lantas, apa saja yang menjadi kompensasi politik itu, sudah pasti yang tau persis adalah para negoisator itu sendiri. Kompensasi politik ini merupakan produk komuniksi politik yang dilakukan oleh aktor-aktor politik. Dampak kompensasi politik ini bisa sangat terbatas, tapi bisa juga sangat luas. Bagaimana interaksi politik yang terjadi di antara pejabat eksekutif dengan anggota legislatif dalam menyikapi konsekuensi negoisasi tersebut - kembali kepada persoalan motivasi politik dan komunikasi politik yang tercermin dari kepentingan politik para aktor politik itu sendiri. Dalam konteks ini, seorang Informan mengungkapkan :

Seandainya dalil itu didasarkan fakta, benar adanya, anggaran itu memang sangat dibutuhkan untuk pembangunan, untuk kebaikan rakyat, tidak merugikan negara, disampaikan secara jujur dan terbuka menurutku konsekuensi negoisasinya ya baik-baik sajalah. Dan tak perlu takut sama KPK. Malah menurutku, aktor-aktor yang melakukan negoisasi anggaran seperti itu layak berharap mendapat kebaikan dari pengabdiannya, begitu, kan? Tapi sebaliknya, seandainya dalil itu tidak didasarkan fakta, tidak benar, anggaran itu sebenarnya untuk tujuan tertentu untuk kepentingan tertentu yang sebanranya tidak berhubungan dengan kebaikan rakyat, bisa merugikan negara, disampaikan dengan cara-cara tertentu menurutku konsekuensi negoisasinya ya kau tau sendirilah. Konsekuensi negoisasi seperti ini pasti negatif.

Berdasarkan deskripsi temuan empirik yangdikemukan disusun model baru sebagai hasil pengembangan applied theory. Model Baru adalah hasil pengembangan applied theory yang dijadikan landasan teoritik penyusunan definisi kosep penelitian. Model baru adalah hasil penerapan epistomologi Ilmu Pemerintahan yang terfokus pada pelaksanaan fungsi-fungsi pemerintahan yaitu fungsi perwakilan (representasi) dan fungsi pengaturan (legislasi). Penerapan epistomologi dilakukan dengan mengadakan kajian manajemen keuangan daerah yang menjadi bagian integral manajemen pemerintahan.

Definisi Model Baru: Berdasarkan landasan teoritik dan temuan empirik yang dikemukakan maka model baru yang dapat disusun dari pembahasan interaksi politik dalam proses penetapan APBD Provinsi Sumatera Utara adalah Model Baru tentang Model Negoisasi Politik Anggaran Bernuansa Positif dengan definisi: Model Negoisasi Politik Anggaran Bernuasa 


\section{ARTIKEL}

Positif adalah pola komunikasi pemerintahan yang berlangsung dalam perumusan, pembahasan dan penetapan kebijakan anggaran yang sepenuhnya untuk kepentingan publik dan anti koropsi, kolusi dan nepotisme yang terungkap dari motif negoisasi, dalil negoisasi dan konsekuensi negoisasi yang bernuansa positif. Dengan definisi ini tercakup tiga dimensi negoisasi politik anggaran: (1) Dimensi motif negoisasi anggaran bernuansa positif, (2) Dimensi dalil negoisasi anggaran bernuansa positif, dan (3) Dimensi konsekuensi negoisasi anggaran bernuansa positif.

Motif Negoisasi Anggaran Bernuansa Positif adalah dorongan internal individu dan atau kelompok yang berasal dari adanya kebutuhan atau harapan tertentu yang berlangsung dalam proses negoisasi kebijakan alokasi anggaran yang diaktualisasikan dengan semangat pengabdian, kejujuran dan kerjasama kelembagaan yang amanah dan bertanggungjawab. Semangat pengabdian hanya bisa tumbuh dan berkembang menjadi kekuatan batin apabila fungsi jabatan eksekutif atau jabatan legislatif diterima dan dilaksanakan dengan kesadaran bahwa jabatan atau kekuasaan itu adalah kepercayaan yang diamanatkan oleh rakyat untuk kepentingan rakyat. Karena itu, pengabdian menjadi pilihan perilaku politik yang menjunjung tinggi kehormatan pribadi dan jabatan; dan dari rangkaian pengabdian perilaku politik itu sesungguhnya terdapat imbalan yang pantas. Kejujuran merupakan pengejawantahan sikap mental yang tidak menggunakan kebohongan untuk melakukan pembenaran segala cara untuk mencapai tujuan tertentu; dan kejujuran menuntut keberanian untuk mengatakan yang sebenarnya. Karena itu, kejujuran menjadi pilihan perilaku politik yang tidak menghalalkan segala cara untuk mencapai tujuan tertentu; dan dari kejujuran itu sesungguhnya muncul kemuliaan dan keselamatan pribadi dan jabatan. Kerjasama kelembagaan yang amanah dan bertanggungjawab merupakan jalinan kerjama institusional dan personal di antara pejabat eksekutif dengan anggota legislatif dalam melaksanakan fungsi manajemen keuangan yang terbentuk oleh peraturan perudang-undangan yang mengatur penyelenggaraan pemerintahan dan pengelolaan keuangan negara; dan melalui jalinan kerjasama tersebut terlaksana berbagai kebijakan, program dan kegiatan lembagalembaga pemerintahan. Pelaksanaan berbagai kebijakan, program dan kegiatan lembaga-lembaga pemerintahan yang amanah dan bertanggungjawab hanya bisa dilakukan secara efektif dan efisien apabila didasarkan pada semangat pengabdian dan kejujuran. Dengan demikian maka Motif Negoisasi Anggaran Bernuansa Positif mencakup tiga indikator interaksi politik yang meliputi indikator semangat pengabdian, indikator kejujuran dan indikator kerjasama kelembagaan yang amanah dan bertanggungjawab. Meskipun tidak semua orang dapat 


\section{ARTIKEL}

mengaktualisasikan tiga indikator tersebut secara optimal; namun kesadaran akan pentingnya tiga indikator Motif Negoisasi Anggaran Bernuansa Positif sudah menjadi langkah awal yang baik untuk melancarkan politik anggaran.

Dalil Negoisasi Anggaran Bernuansa Positif adalah penjelasan, alasan dan argumen tertentu yang menyertai suatu perencanaan anggaran yang berlangsung dalam proses negoisasi anggaran yang diaktualisasikan dengan deskripsi manajerial dan data fungsional alokasi anggaran. Deskripsi manajerial meliputi sasaran dan target kinerja, rencana program dan uraian kegiatan, kaidah pelaksanaan kegiatan. Deskripsi manajerial merujuk pada sasaran pokok perencanaan pembangunan jangka menengah, prinsip dasar penyusunan rencana kerja pembangunan, prioritas dan sasaran pembangunan, identifikasi masalah penyelenggaraan urusan pemerintahan, dan arah kebijakan pembangunan. Data fugsional alokasi anggaran meliputi pagu indikatif, sasaran dan target kegiatan, struktur anggaran, dan indikator kinerja anggaran. Data fungsional alokasi anggaran merujuk pada arah kebijakan belanja dan arah kebijakan pembiayaan serta hasil penelusuran dan pembahasan spesifikasi dan standarisasi barang atau jasa dan rincian harga. Penyusunan deskripsi manajerial dilakukan dengan mengadakan kajian dokumen rencana strategis dan dokumen-dokumen lainnya yang terkait dengan arah kebijakan pembangunan. Penyusunan data fungsional alokasi anggaran dilakukan dengan merancang indikator-indikator kinerja anggaran serta memperhatikan kebijakan pengelolaan dan tanggungjawab keuangan negara. Jika kinerja penyusunan deskripsi manajerial dan kinerja penyusunan data fungsional alokasi anggaran dilakukan dengan semangat pengabdian, kejujuran dan kerjasama para pihak yang profesional dan akuntabel tentu akan tersusun Dalil Negoisasi Anggaran Bernuansa Positif. Dengan demikian maka Dalil Negoisasi Anggaran Bernuansa Positif mencakup tiga indikator interaksi politik yang meliputi indikator semangat pengabdian, indikator kejujuran dan indikator kerjasama para pihak yang profesional dan akuntabel. Meskipun tidak semua orang dapat mengoptimalkan tiga indikator tersebut; namun kesadaran akan pentingnya tiga indikator Dalil Negoisasi Anggaran Bernuansa Positif sudah menjadi langkah awal yang baik untuk melancarkan politik anggaran.

Konsekuensi Negoisasi Anggaran Bernuansa Positif adalah tanggungan, akibat dan dampak tertentu yang menyertai suatu perencanaan anggaran yang berlangsung dalam proses negoisasi anggaran yang diaktualisasikan dengan analisis risiko dan analisis akuntabilitas kinerja anggaran. Analisis risiko adalah penelusuran dan penelaahan tanggungan, akibat dan 


\section{ARTIKEL}

dampak tertentu yang timbul dari penggunaan anggaran yang perlu diantisipasi sejak disetujuinya perencanaan anggaran. Analisis risiko dilakukan dengan cara menelusuri dan menelaah setiap hal yang diperkirakan akan timbul dan dapat merugikan para pihak, karena capaian kinerja anggaran tidak optimal dan teknis kegiatan terkendala. Penelusuran dan penelaahan tersebut dilakukan untuk menghasilkan catatan-catatan yang menjadi dasar dilakukannya pendekatan manajemen risiko. Akuntabilitas kinerja anggaran adalah pertanggungjawaban atas proses dan hasil penggunaan anggaran yang menyertai perencanaan anggaran yang berlangsung dalam proses negoisasi anggaran yang diaktualisasikan dengan analisis akuntabilitas kinerja dan analisis akuntabilitas anggaran. Analisis akuntabilitas kinerja adalah penelusuran dan penelaahan proses dan hasil pelaksanaan kegiatan atau pekerjaan yang meliputi berbagai aspek teknis dan waktu penyelesaian. Analisis akuntabiltas kinerja dilakukan dengan cara menelusuri dan menelaah ukuran-ukuran produktivitas, efektivitas dan efisiensi seluruh rangkaian teknis pelaksanaan kegiatan atau pekerjaan menurut kebijakan alokasi anggaran yang sudah ditetapkan sebelumnya. Analisis akuntabiltas anggaran adalah penelusuran dan penelaahan proses dan hasil penggunaan anggaran kegiatan atau pekerjaan. Analisis akuntabiltas anggaran dilakukan dengan cara menelusuri dan menelaah bentuk-bentuk dan ukuran-ukuran pertanggungjawaban anggaran menurut kebijakan alokasi anggaran yang sudah ditetapkan sebelumnya. Jika analisis akuntablitas kinerja dan analisis akuntablitas anggaran dilakukan dengan semangat pengabdian, kejujuran dan sinergitas para pihak secara profesional dan akuntabel tentu akan terprediksi Konsekuensi Negoisasi Anggaran Bernuansa Positif. Dengan demikian maka Konsekuensi Negoisasi Anggaran Bernuansa Positif mencakup tiga indikator interaksi politik yang meliputi indikator semangat pengabdian, indikator kejujuran dan indikator sinergitas para pihak secara profesional dan akuntabel. Meskipun tidak semua orang dapat mengoptimalkan tiga indikator tersebut; namun kesadaran akan pentingnya tiga indikator Konsekuensi Negoisasi Anggaran Bernuansa Positif sudah menjadi langkah awal yang baik untuk melancarkan politik anggaran.

Berdasarkan deskripsi Model Negoisasi Politik Anggaran Bernuansa Positif dapat disusun Proposisi sebagai berikut: Motif negoisasi anggaran bernuansa positif, dalil negoisasi anggaran bernuansa positif, dan konsekuensi negoisasi anggaran bernuansa positif menentukan efektivitas interaksi politik dalam proses penetapan anggaran pendapatan dan belanja. 


\section{ARTIKEL}

\section{KESIMPULAN}

Model baru yang dapat disusun dari pembahasan interaksi politik dalam proses penetapan APBD Provinsi Sumatera Utara adalah model negoisasi politik anggaran bernuansa positif, yaitu pola komunikasi pemerintahan yang berlangsung dalam perumusan, pembahasan dan penetapan kebijakan anggaran yang sepenuhnya untuk kepentingan publik dan anti koropsi, kolusi dan nepotisme yang terungkap dari motif negoisasi, dalil negoisasi dan konsekuensi negoisasi yang bernuansa positif. Definisi ini mencakup tiga dimensi negoisasi politik anggaran yaitu: Dimensi motif negoisasi anggaran bernuansa positif, Dimensi dalil negoisasi anggaran bernuansa positif, dan Dimensi konsekuensi negoisasi anggaran bernuansa positif.

\section{DAFTAR PUSTAKA}

Arikunto, S. (2007). Prosedur Penelitian, Suatu Pendekatan Praktek. Jakarta: Rineka Cipta.

Creswel, J. W. (1994). Research Design Qualitative \& Quantitative Approaches. New Delhi: Sage Publication.

Almond, G. A., \& Verba, S. (1963). The Civic Culture: Political Attitudes and Democracy in Five Nations. Princeton: Princeton University Press

Bardis, D. P. (1978). Social Interaction and Social Processes dalam Jurnal International Behavioural Scientist, December (1978:7-32), in International Honor Society in Social Sciences (2014)

Christensen, T., \& Laegreid, P. (2002). Complex Patterns of Interaction and Influence among Political and Administrative Leaders. Stein Rokkan Centre for Social Studies, Bergen University Research Foundation.

Duignan, B. (2013). Political Systems, Structures and Functions. Governance: Power, Politics and Participation. Britannica Educational Publishing.

Easton, D. (1992). Aproaches to the Study of Politics. New York: Macmillan Publishing Company.

Kai Jo Fu. The Interaction of Politics and Management in Public Leadership: Measuring Public Political Skill and Assessing Its Effects. The Graduate School Florida State University Libraries

Zeehandelaar, D. B. (2012). The Local Politics of Education Governance: Power and Influence among School Boards, Superintendents, and Teachers' Unions. Dissertation in Faculty of the Usc Graduate School University of Southern California. 